\title{
The Neurological Improvement of a Patient after Amantadine Infusion
}

\author{
Amantadin İnüzyonu Sonrası Nörolojik Iyileşme
}

Nalan Metin Aksu, Huleyde Şenlikçi, Meltem Akkaş, Mehmet Mahir Özmen

Department of Emergency, Faculty of Medicine, Hacettepe University, Ankara, Turkey

\section{ABSTRACT}

Amantadine is a dopaminergic agent with possible N-methylD-aspartate antagonist effects. Dopaminergic agents have been succesfully used for many purposes, including prophylaxis for influenza, adjunctive therapy for psychiatric diseases, treatment for Parkinson Disease, and treatment for disorders of consciousness. In this case report, amantadine infusion was started in a patient whose unconciousness could not be identified for ten days. A dramatic recovery was detected on the second day following amantadine infusion. The patient was discharged on the twenty-first treatment day with a 15 GCS score. Conclusion: Amantadine may be added to the standard therapy in comatose patients as it accelerates neurological functional recovery.

Keywords: Dopaminergic agents, amantadine, consciousness Received: 13.07.2012 Accepted: 28.07.2012

\section{ÖZET}

Amantadin, N-methyl-D-aspartate antagonist özelliği ile dopaminerjik etki gösteren bir ajandır. Dopaminerjik ajanlar; psikiyatrik hastalıkların tamamlayıcı, Parkinson Hastalığı ve bilinç bozuklukları tedavisinde ve influenza profilaksisinde başarıyla kullanılmaktadır. Bu olgu sunumunda nedeni tam olarak belirlenemeyen GKS 7 olan komadaki bir hastada izleminin 10. gününde amantadin infüzyonu başlandı. Amantadin infüzyonunun 2. gününden itibaren dramatik düzelme görülen hasta izleminin 21. günü GKS 15 olarak taburcu edildi. Amantadin tedavisi, koma hastalarında iyileşmeyi hızlandırdığı ve arttırdığı için standart tedaviye ilave olarak kullanılabilir.

Anahtar Kelimeler: Dopaminerjik ajan, amantadin, bilinç bozukluğu

Geliş Tarihi: 13.07.2012 Kabul Tarihi: 28.07.2012

\section{Giriş}

Amantadin, N-methyl-D-aspartate antagonist özelliği ile dopaminerjik etki gösteren bir ajandır (1). Dopaminerjik ajanlar; influenza profilaksisi, psikiyatrik hastalıkların tamamlayıcı tedavisi, Parkinson Hastalığı tedavisi ve bilinç bozuklukları tedavisinde başarıyla kullanıımaktadır (2). Bu yazı ile, amantadin infüzyonu sonrasında bilinç bozukluğunda iyileşme olan meningoensefalit tedavisi alan bir hastanın sunulması amaçlanmışır.

\section{Olgu Sunumu}

Altmış üç yaşında bayan hasta Acil Servis'e bilinç bulanıklığı, genel durum bozukluğu ve ateş şikayeti ile getirildi. Bir gün önce dış merkezde meningoensefalit tanııı ile seftriakson ve asiklovir tedavisi başlanmıştı. Özgeçmişinde hipertansiyon hastalığı mevcuttu. Geliş hayati bulguları arasında N: 118/dk, KB: 131/77 mm/hg, Ateş: 39,8 C, O, sat: \%94, ve fizik bakı bulguları olarak bilinci kapalı, Glaskow Koma Skalası (GKS): 7 ve ense sertliği olan hasta entübe edildi. Laboratuar tetkiklerinde BK: 23000/mm³, AST/ALT: 56/32 U/L, Na: 129 mEq/L, INR: 1,35 olarak bulundu. BBT'nde subaraknoid kanama şüphesi olması üzerine, nöroşirürji bölümü önerileri de alınarak, lomber ponksiyon LP yapıldı. Beyin omurilik sIVIII (BOS) mikroskobik bakısı temiz olan hastaya enfeksiyon hastalıkları bölümünün önerisiyle menenjit ön tanısı ile ampisilin $6 \times 2$ gr, seftriakson $2 \times 2$ gr, asiklovir $3 \times 750$ mg başlandı ve hasta acil servise bağlı yoğun bakım ünitesinde izleme alındı. BOS kültüründe üreme tespit edilmemesi ve kliniğin düzelmemesi nedeniyle 5 gün sonra hastaya tekrar L/P yapıldı. Kullanmakta olduğu seftriakson kesilerek, yerine meropenem 3x1 gr başlandı. Hastanın takibinde bilincinde açılma olmayınca beyin- boyun BT anjiyografi yapıldı ama bir patoloji saptanmadı. Morbid obeziteden dolayı beyin 
Magnetik Rezonans Görüntüleme (MRG) cihazına uyumlu olmayan hastaya beyin MRG çekilemedi. Hastanın izleminin 10. gününde; bilincinde düzelme olmaması (GKS: 6) nedeniyle amantadin sulfat çözeltisi (PK-Merz (Merz Pharmeuticals ${ }^{\circledR}$, Franfurt,Almanya) 1×200 mg 3 saatlik infüzyon halinde başlandı. Tedavinin ikinci gününde GKS'si 7 olan hastaya portabl Elektroensefalografi (EEG) çekildi ve yavaş dalgalarla karakterize paroksismal bozukluk tespit edildi. 3. günde GKS'si 10 olan hastanın bilinci açıldı. 4. gün genel durumu düzelen hasta ekstübe edildi, hastaya tekrar EEG çekildi ve daha önce belirtilen yavaş dalga aktivitesinde belirgin hılanma tespit edildi. Dördüncü gün hastanın amantadin tedavisi kesildi. Aynı gün tekrarlayan L/P kültüründe de üreme olmaması ve hastanın genel durumunun düzelmesi üzerine meropenem-asiklovir tedavisi kesilerek, ampisilin 21 güne tamamlanmasına karar verildi. Hasta antibiyotik tedavisinin 21. günü genel durumu iyi ve GKS 15 olarak taburcu edildi.

\section{Tartışma}

Santral sinir sistemindeki nörotransmitter sistemlerinden olan glutamaterjik sistem uyanıklığı baskılar. Glutamat anatagonisti olan amantadin, glutamaterjik yolu kullanarak hedef nöronda NMDA-ilişkili kalsiyum kanal bağımlı postsinaptik membran uyarımının azalmasına yardımcı olarak uyanıklığı arttırır (3). Bu özelliklerinden dolayı amantadin, Parkinson Hastalığının şiddetli ve yaşamı tehdit eden vakalarında ve belirtilerin akut alevlenmesi sırasında acil ve yoğun bakım tedavisi olarak ve uyanıklığı ve duyusal algıyı arttırmak amacıyla (değişik kaynaklı koma hastalarında ek tedavi ajanı olarak; travmatik beyin hasarı/ ameliyat, anestezi sonrası uyanma ve benzeri durumda) kullanılır.

Amantadin travmatik beyin yaralanmalarından (TBY) sonra gelişen uzun süreli bilinç bozukluklarında fonksiyonel iyileşmeyi hızlandırdığı için en çok kullanılan ilaçtır (4). Amantadinin TBY'de kullanımı ile ilgili bir çok çalışma vardır (5-8). Giacino ve ark.ının (4) 184 vakalık TBY serisinde amantadinin posttravmatik bilinç bulanıklığı bozukluklarında fonksiyonel iyileşmeyi hızlandırdığı belirtilmektedir. Sawyer ve ark. (9) yaptıkları meta analiz çalışması ile 200-400 mg/gün amantadin tedavisinin TBY hastalarında uyanıklık ve bilinç düzeyinde iyileşmeyi hızlandırdığını tespit etmişlerdir. Akut inme hastalarında kullanımını destekleyen çalışmalar da mevcuttur. Krivanus ve ark. akut inme hastalarında 10 gün boyunca 200 mg/gün amantadin sülfat tedavisinin klasik tedaviye ek olarak kullanılmasının nörolojik defisit oluşumunu azalttığını göstermişlerdir (10). Wu ve ark. (11) vaka raporlarında ventriküler fibrilasyon nedeniyle arrest olan ve 20-25 dk. sonra spontan dolaşımı gelen hastanın yatışının 11-22. günleri arasında amantadin sülfat infüzyonu aldığını ve 22. günde hastanın yardımla ayağa kalkabildiğini yayınlamışlardır. Değişik kaynaklı bilinç bozukluklarında zolpidem, baklofen ve amantadin gibi santral sinir sistemi stimülanı ilaçların dramatik iyileşmeler sağladığı gösterilmiştir (12). Bizim hastamızda ise tetkiklerle desteklenemeyen şüpheli meningoensefalit tanısı mevcuttu ve hasta 10 gün boyunca koma tablosundaydı. Bu süre zarfında geniş spektrumlu antibiyotik tedavisi de almaktaydı. Hastanın bilinç düzeyinde iyileşme olmadığı için amantadin sülfat infüzyonu başlandı. Tedavinin etkinliği, 2. günden itibaren nörolojik bulguların düzelmesi ve tedavinin 4. gününde tam nörolojik iyileşme ile klinik olarak gözlemlendi. Tedavi öncesi ve tedavinin 2. günü yapılan EEG analizlerinin karşılaştırılması ile de sonuç doğrulandı.

\section{Sonuç}

Amantadin, değişik kaynaklı koma hastalarında iyileşmeyi hızlandırdığı ve arttırdığı için standart tedaviye eklenebilir. Tedaviye başlarken hastada ileri derecede kalp yetmezliği, kalpte iletim bozuklukları ve böbrek yetmezliği olmamasına dikkat edilmelidir. Illacın erken dönemde başlanması hastanın nörolojik iyileşmesini hızlandıracağı için bu tarz hastalarda tedaviye acil tıp doktoru da başlayabilir.

\section{Conflict of Interest}

No conflict of interest was declared by the authors.

Peer-review: Externally peer-reviewed.

\section{Author Contributions}

Concept - N.M.A.; Design - N.M.A., M.A.; Supervision - M.M.Ö.; Funding - H.Ş.; Materials - H.Ş.; Data Collection and/or Processing - H.Ş.; Analysis and/or Interpretation - N.M.A., M.A.; Literature Review N.M.A., M.A.; Writer - N.M.A., M.A., H.Ş.; Critical Review - M.M.Ö

\section{Çıkar Çatışması}

Yazarlar herhangi bir çıkar çatışması bildirmemişlerdir.

\section{Hakem değerlendirmesi: Dış bağımsız.}

\section{Yazar Katkıları}

Fikir - N.M.A.; Tasarım - N.M.A., M.A.; Denetleme - M.M.Ö.; Kaynaklar H.Ş.; Malzemeler - H.S.; Veri toplanması ve/veya işlemesi - H.S.; Analiz ve/veya yorum - N.M.A., M.A.; Literatür taraması - N.M.A., M.A.; Yazıyı yazan - N.M.A., M.A., H.Ş.; Eleştirel İnceleme - M.M.Ö

\section{Kaynaklar}

1. Meythaler JM, Brunner RC, Johnson A, Novack TA. Amantadine to improve neurorecovery in traumatic brain injury-associated diffuse axonal injury: a pilot double-blind randomized trial. J Head Trauma Rehabil 2002; 17: 300-13. [CrossRef]

2. Wu ST, Garmel MG. Improved neurological function after amantadine treatment in two patients with brain injury. J Emerg Med 2005; 28: 289-92. [CrossRef]

3. Saniova B, Drobny M, Kneslova L, Minarik M. The outcome of patients with severe head injuries treated with amantadine sulphate. J Neurol Trans 2004; 111: 511-4. [CrossRef]

4. Giacino JT, Whyte J, Bagiella E, Kalmar K, Childs N, Khademi A, et al. Placebo-controlled trial of amantadine for severe traumatic brain injury. $\mathrm{N}$ Engl J Med 2012; 366: 819-26. [CrossRef]

5. Tenovuo O. Pharmacological enhancement of cognitive and behavioral deficits after traumatic brain injury. Curr Opin Neurol 2006; 19:528-33. [CrossRef]

6. Neurobehavioral Guidelines Working Group, Warden DL, Gordon B, McAllister TW, Silver JM, Barth JT, et al. Guidelines for the pharmacologic treatment of neurobehavioral sequelae of traumatic brain injury. J Neurotrauma 2006; 23: 1468-501. [CrossRef]

7. Napolitano E, Elovic EP, Qureshi Al. Pharmacological stimulant treatment of neurocognitive and functional deficits after traumatic and non-traumatic brain injury. Med Sci Monit 2005; 11: 212-20.

8. Kraus MF, Smith GS, Butters M, Donnell AJ, Dixon E, Yilong C, et al. Effects of the dopaminergic agent and NMDA receptor antagonist amantadine on cognitive function, cerebral glucose metabolism and D2 receptor availability in chronic traumatic brain injury: a study using positron emission tomography (PET). Brain Injury 2005; 19: 471-9. [CrossRef] 
9. Sawyer E, Mauro LS, Ohlinger MJ. Amantadine enchancement of arousal and cognition after traumatic brain injury. Ann Pharmacother 2008; 42: 247-52. [CrossRef]

10. Krivonos OV, Amasova NA, Smolentseva IG. Use of the glutamate NMDA receptor anatagonist PK-Merz in acute stroke. Neurosci and Behav. Physio 2009; 40: 72-4.
11. Wu ST, Garmel GM. Improved neurological function after amantadine treatment in two patients with brain injury. J Emerg Med 2005; 28: 289-92. [CrossRef]

12. Pistoia F, Mura E, Govoni S, Fini M, Sara M. Awakenings and awareness recovery in disorders of consciousness:is there a role for drugs? CNS Drugs 2010; 24: 625-38. [CrossRef] 